\title{
STUDENTS SHORTLISTED FOR NATIONAL DENTAL PROFESSIONAL AWARDS
}

Two University of Plymouth students have been shortlisted for the Future of Dentistry awards, recognising the upcoming talent in the profession.

Nicole Elango and Deeon Trute are finalists for the Student Dentist of the year and Student Dental Hygienist and/ or Therapist of the Year 2020 respectively - marking the first time that two Plymouth students have been shortlisted simultaneously.

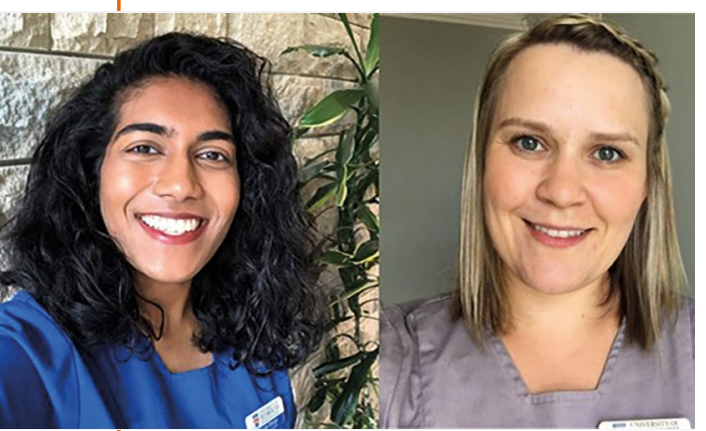

The students were selected from hundreds of national applications, and the winners will be announced later this year.

Nicole is a third year student dentist and took on the degree having already achieved a BSc in Biomedical Sciences and MSc Mental Health.

She has been 2019-20 President of Peninsula DentSoc, Dental Course Rep, Student Representative for the British Dental Association and a mentor for aspiring dental students. She has spent over 600 hours as a suicide hotline volunteer, and volunteered with a local Plymouth charity to produce an intervention to alleviate dental anxiety, and teach basic oral hygiene instructions to children with special educational needs and their parents.

Nicole said: 'I am incredibly grateful to be a finalist for the dental student of the year award. I feel privileged to be able to complete my degree at Peninsula and I look forward to spending time giving back to the student and dental community through continued mentoring, volunteering and teaching. Most importantly, I am thankful for the support provided from my family, friends, and staff at Peninsula Dental School over the years.
Deeon has been working within dentistry for 10 years - starting as a trainee dental nurse as soon as she finished her A Levels, after being inspired by her own dentist.

\section{'The students were} selected from hundreds of national applications, and the winners will be announced later this year'

She then moved to Plymouth and did some part time locum work, then sought to realise her ambition to help patients of her own improve their oral health.

Alongside her studies in dental therapy and hygiene, Deeon is a mentor on the Widening Access to Dental School (WADs) e-mentoring scheme, supporting people interested in becoming dental professionals of the future, and a dental therapy and hygiene equality and diversity champion. She has also worked closely with outreach charity Well Connected to support and educate the Plymouth community on oral health.

Deeon, who has just finished her third year, said: 'I'm so happy to be shortlisted for this award and have loved studying the course at Plymouth. As well as the academic and practical side of dental hygiene therapy, I've been able to work with the local community and really understand their needs. I plan to stay living in Plymouth and I would love to continue working within the local community, to help educate and support those that need it.'

Professor Christopher Tredwin, Head of Peninsula Dental School, said: 'We are proud of all of our students' impact on their local community, and it's wonderful to see that Nicole and Deeon's outstanding achievements have been recognised nationally. They've done some exceptional work to make a difference to their peers and communities in need, and to hear that they'll carry on their work after graduating is wonderful. Their shortlistings are very well deserved indeed.'

\section{Patel urged to drop plans for inaccurate, unethical dental checks on migrants}

The British Dental Association has urged Home Secretary Priti Patel to think again on plans to introduce dental checks to establish the age of Channel migrants.

According to reports, a new independent nationwide panel will use dental records and other 'scientific evidence' to verify the age of asylum seekers. The Association has vigorously opposed the use of dental X-rays to determine whether asylum seekers have reached the age of 18 , stressing they are an inaccurate method for assessing age.

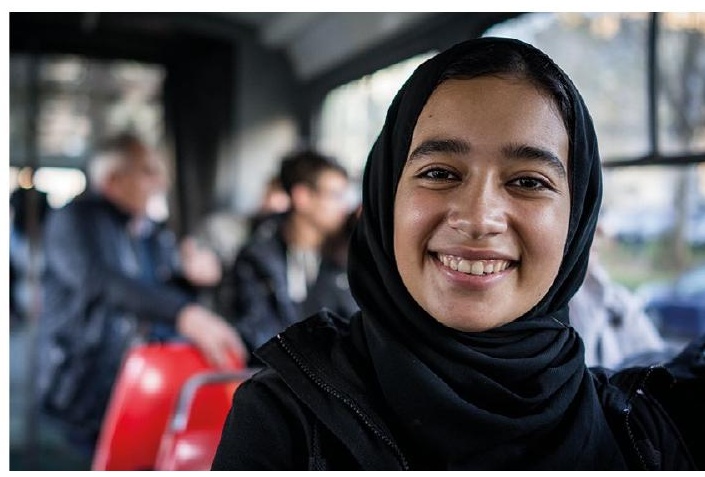

The BDA also believes that it is inappropriate and unethical to take radiographs of people when there is no health benefit for them. X-rays taken for a clinically justified reason must not be used for another purpose without the patient's informed consent and must be carried out without coercion and in full knowledge of how the radiograph will be used and by whom.

The new Nationality and Borders Bill will give the Home Secretary the powers to introduce methods of assessing age via regulation.

This new position runs counter to statements adopted by the Home Office in 2016, when the Department rejected similar calls from backbencher David Davies MP.

BDA Chair Eddie Crouch said: 'This is a retrograde step from Priti Patel.

'In 2016 the Home Office ruled out dental checks for migrants, which we considered inaccurate, inappropriate and unethical. In 2021 the science and ethics have not changed.' 